\title{
GMR
}

\section{Strategy for selection of soybean genotypes tolerant to drought during germination}

\author{
S.A.G. Dantas, F.C.S. Silva, L.J. Silva and F.L. Silva \\ Departamento de Fitotecnia, Universidade Federal de Viçosa, Viçosa, MG, Brasil \\ Corresponding author: S.A.G. Dantas \\ E-mail: stenioandrey@gmail.com
}

Genet. Mol. Res. 16 (2): gmr16029654

Received February 23, 2017

Accepted March 31, 2017

Published May 10, 2017

DOI http://dx.doi.org/10.4238/gmr16029654

Copyright (C) 2017 The Authors. This is an open-access article distributed under the terms of the Creative Commons Attribution ShareAlike (CC BY-SA) 4.0 License.

\begin{abstract}
Water deficit is the main reason for instability in the context of soybean culture. The development of strategies for the selection of more tolerant genotypes is necessary. These strategies include the use of polyethylene glycol 6000 solutions (PEG-6000) for conducting the germination test under conditions of water restriction. Thus, the objective of this study was to determine the osmotic potential and the main characteristics that promote the discrimination of soybean genotypes with regard to water stress tolerance during germination and the vigor test. Thirteen soybean cultivars were used. The seeds were allowed to germinate on sheets of germitest paper moistened in solution with PEG-6000, simulating different levels of water availability, which is expressed as osmotic potential $(0.0,-0.2,-0.4$, and $-0.6 \mathrm{MPa})$. We assessed germination, length, and dry mass for seedlings and seeds, as well as reserve dynamics. Germination and variables related to the dynamics of reservation have great influence on the expression of variability in environments under stress. Among the different osmotic potentials, the $-0.2 \mathrm{MPa}$ was the most efficient for the expression of genetic variability among the cultivars. Conducting the germination test with PEG-6000 solution to $-0.2 \mathrm{MPa}$ was efficient for selecting soybean cultivars tolerant to water stress. This was accomplished by
\end{abstract}

Genetics and Molecular Research 16 (2): gmr16029654 
evaluating the percentage of germination, along with variables related to the dynamics of reservation.

Key words: Glycine max (L.) Merrill; Genetic breeding; Stress level; Polyethylene glycol (PEG-6000); Drought tolerance

\section{INTRODUCTION}

While the effects of water stress following the establishment of cultures have been widely studied and elucidated, the survival of plants under drought during the establishment of culture has rarely been considered. The initial establishment of seedlings is obviously the first step to succeeding in the production of diverse cultures, primarily in water-deficit conditions, in which potential differences between the survival rates of plants under these conditions may result in better training of booth, ensuring greater stability (Marrou et al., 2015).

The establishment of the culture of soybean is directly related to the vigor of seed (Henning et al., 2010). Vigor is a set of properties that contribute to indicate the quality of the seed; these properties related to its potential for germination, seedling emergence, and storage capacity under different environmental conditions are considered standard (Sun et al., 2007).

The initial vigor of plants can be measured through the evaluation of hypocotyl, root, and seedling characteristics, as the length (HL and RL) and dry mass (Vanzolini et al., 2007), as well as through the analysis of seed reserves (Henning et al., 2010). It is important to note that these features when present genetic variability can be considered in breeding programs (Pereira et al., 2015) and a strategy on the selection of superior genotypes.

For studies of selection of soybean genotypes tolerant to water deficit involving germination and vigor tests, several authors have observed the effectiveness of these tests in conditions of low osmotic potential simulated with polyethylene glycol (PEG), applying from the use in studies of genetic diversity, differentiation and grouping of soybean genotypes most tolerant to water stress (Teixeira et al., 2008a,b); as well as to the relationship of genotype response during this test with its performance on the field, and subsequently with productivity (Kosturkova et al., 2008).

However, there is no consensus that the differences regarding the response to water deficit in the germination stage of cultivars are entirely consistent with the response to water deficit by evaluating data of productivity (Mederski and Jeffers, 1973; Oya et al., 2004). This is perhaps because there is not yet a standardized methodology for the simulation of water deficit and the level of stress that the seed must be submitted during the germination test for discrimination of tolerant or susceptible genotypes, and the identification of important features to be assessed that would lead to such discrimination.

The objective of this study was to determine the osmotic potential and the main characteristics to be evaluated that promote discrimination of soybean genotypes as tolerance to water stress during germination and vigor.

\section{MATERIAL AND METHODS}

The test was conducted in the Oilseed Breeding Laboratory, Plant Science Department of Universidade Federal de Viçosa (UFV), Minas Gerais, Brazil. Thirteen soybean cultivars were used: UFV 16, UFVS 2001, UFVS 2002, UFVS 2003, UFVS 2004, UFVS 2008, UFVS

Genetics and Molecular Research 16 (2): gmr16029654 
2009, UFVS Quartzo, UFVS Turquesa, UFVS Berilo, UFVS Opala, TMG 1179 RR, and MG/ BR Conquista. The seeds used in this study were produced under field conditions in 2014/2015 in experimental field of UFV, and, immediately after harvesting, drying at room temperature, and cleaning, the seeds were standardized as to size in $\mathrm{mm}$ sieve, and then was carried out the test, thus ensuring that all tests were conducted with freshly harvested seeds, as recommended by Soltani et al. (2006). The seeds were subjected to the following tests and measurements.

\section{Determination of the moisture and dry mass of seeds}

To determine seed water content, three replications of 50 seeds were weighted (W1) and taken to air circulation oven at $105^{\circ} \mathrm{C}$ for $24 \mathrm{~h}$, and then reweighed (W2) on analytical scales. The seed dry mass (SDM) was calculated as [(W1 - W2) / W2)]. For the purpose of this study, the SDM was considered as the total reserves of the seed available to be mobilized to seedlings.

\section{Germination}

The germination test was conducted with four replications of 50 seeds, distributed on two sheets of germitest paper moistened with solutions in different stress levels, expressed as osmotic potential: $0.0,-0.2,0.4$, and $0.6 \mathrm{MPa}$. Each stress level has been obtained by adding PEG-6000 to distilled water at a temperature of $25^{\circ} \mathrm{C}$, in accordance with the recommendation of Villela et al. (1991). The roles were moistened with their respective solutions at a rate of three times their dry weight. After the distribution of the seeds on two sheets of germitest paper, these were covered with a sheet of germitest paper and made the rolls, which were brought to germination at the regulated temperature of $25^{\circ} \mathrm{C}$, with a 12 -h light/12-h dark as stated in rules for seed analysis (Brasil, 2009).

The counts of the number of normal seedlings were conducted at five (first count of germination - FC) and 7 days (germination - GR) after sowing. The results are reported as percentage.

\section{Seedling growth and reservation dynamics}

Seedling growth test was performed with four repetitions of 10 seeds each, distributed longitudinally on the upper third of the germitest paper with their micropil parts directed to the base of the paper. Seven days after sowing, the rootlets and the hypocotyls of normal seedlings were measured with a ruler. The results are reported in $\mathrm{cm}$.

Then, the radicle, the hypocotyl, and the cotyledons were separated and placed to dry at $80^{\circ} \pm 1^{\circ} \mathrm{C}$ for $24 \mathrm{~h}$. After this period, the plant material was weighed on analytical scales, separately, for evaluation of radicle dry mass (RDM), hypocotyl dry mass (HDM), and cotyledon dry mass (CDM).

Due to the need for standardization with the SDM data, which is an average of 50 seeds put out to dry, the values obtained individually from dry mass for each plant tissue, described earlier, were added and multiplied by 50 , which yielded an approximate value of total dry mass estimated for 50 plants (PDM) at 100\% germination (Soltani et al., 2002, 2006; Pereira et al., 2015).

From the remaining CDM and the SDM it was possible to obtain the value of the

Genetics and Molecular Research 16 (2): gmr16029654 
reduction of seed reserves (RSR) for estimator: RSR $=\mathrm{SDM}-\mathrm{CDM}$. Following the same reasoning and based on the values of PDM, the efficiency of conversion of reserves (ECR) was determined, which corresponded to the SDM conversion in seedling dry mass, using the estimator: $\mathrm{ECR}=\mathrm{PDM} / \mathrm{RSR}$. And finally, it was determined the rate of RSR (RRSR), obtained by the estimator: RRSR $=$ RSR / SDM, which allows to identify the cultivar that mobilized the greater SDM for the establishment of seedlings (Soltani et al., 2006).

\section{Statistical analyses}

Statistical analysis of the data was divided into five stages: the first stage was a multivariate analysis of the Mahalanobis distance among four stress environments, considering all the genotypes as a single source of variation, including cluster analysis based on the link between averages (UPGMA); in the second stage, analysis of variance was performed to study the interaction genotype $\mathrm{x}$ stress levels; the third stage was to determine the osmotic potential great for discrimination of varieties as the stress level; the fourth stage was to identify the features that contribute most to the cultivar discrimination osmotic potential great; and the fifth was a simple correlation analysis between the characteristics in the potential of $-0.2 \mathrm{MPa}$.

For the third step, the data were organized so that stress levels were considered as variables. The analysis of relative contribution to genetic diversity was conducted using the methodology of Singh (1981) within each variable and all simultaneously.

All analyses were performed using the Genes program (Cruz, 2013).

\section{RESULTS AND DISCUSSION}

The levels of simulated stress achieved with PEG-6000 showed divergence $(0.0$ $\mathrm{MPa}$ ), when compared in terms of Mahalanobis distance. Between the stress conditions, the environment conditioning by potential $-0.2 \mathrm{MPa}$ proved to be distinct from the other; however, no significant difference were observed between the potential -0.4 and $-0.6 \mathrm{MPa}$, indicating that these stress levels cause the same effects in similar magnitudes on the seeds (Figure 1).

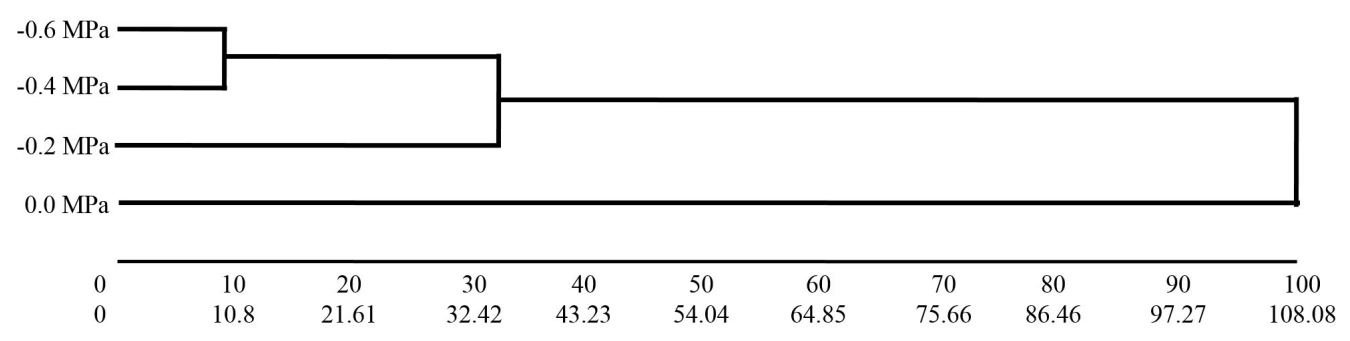

Figure 1. Cluster analysis based on connection between groups (UPGMA) for four potential osmotic conditions on 13 genotypes and 10 variables.

There was statistical significance for interaction genotype $\mathrm{x}$ stress levels for the F-test at $5 \%$ probability for all traits evaluated, demonstrating that the cultivars respond differently at each stress level. Analyzing the unfolding of the interaction, it was found the expression of genetic variability among genotypes to be explored within each level of stress (results

Genetics and Molecular Research 16 (2): gmr16029654 
not shown), being the need for identification of osmotic potential great for discrimination of cultivars in tolerant and susceptible.

The stress level 0.0 MPa (control) had a major influence on the genetic variability for all analyzed variables influencing $37 \%$ of general diversity (Table 1). The high variability within the $0.0 \mathrm{MPa}$ stress due to the natural genetic diversity exists between cultivars for characteristics related to seed vigor, a fact noted as much on culture of soybean (Santos et al., 2012; Pereira et al., 2015), as well as in other cultures, such as rice (Yu et al., 1999), wheat (Soltani et al., 2001), and corn (Sun et al., 2001).

Table 1. Relative importance of levels of stress (osmotic potential) induced by PEG-6000 for the genetic diversity of 13 characteristics of soybean genotypes.

\begin{tabular}{l|c|c|c|c|c|c|c|c|c|c|c}
\hline Level of stress (MPa) & FC & GR & RDM & HDM & CDM & RL & HL & RSR & ECR & RRSR & All variables \\
\hline 0.0 & $82 \%$ & $19 \%$ & $53 \%$ & $45 \%$ & $45 \%$ & $28 \%$ & $21 \%$ & $49 \%$ & $12 \%$ & $54 \%$ & $37 \%$ \\
\hline-0.2 & $18 \%$ & $15 \%$ & $33 \%$ & $20 \%$ & $29 \%$ & $47 \%$ & $16 \%$ & $32 \%$ & $31 \%$ & $29 \%$ & $43 \%$ \\
\hline-0.4 & $0 \%$ & $24 \%$ & $8 \%$ & $10 \%$ & $19 \%$ & $18 \%$ & $36 \%$ & $18 \%$ & $9 \%$ & $16 \%$ & $14 \%$ \\
\hline-0.6 & $0 \%$ & $42 \%$ & $6 \%$ & $25 \%$ & $7 \%$ & $7 \%$ & $28 \%$ & $1 \%$ & $48 \%$ & $1 \%$ & $6 \%$ \\
\hline
\end{tabular}

FC - first count; GR - germination; RDM, HDM, and CDM - dry mass of root, hypocotyl, and cotyledons; RL and HL - root and hypocotyl length; RSR - reduction of seed reserves; ECR - efficiency of conversion of reserves; RRSR - reduction rate of seed reserves.

Among the four osmotic potentials tested, $0.2 \mathrm{MPa}$ allowed for the greatest expression of genetic variability among the genotypes studied (43\%) (Table 1).

When considered in isolation each feature within the four levels of stress, one can realize that of the ten that were evaluated, the stress of $-0.2 \mathrm{MPa}$ was responsible for the largest variation in six (FC, RDM, CDM, RL, RSR, and RRSR), while the stresses -0.4 and -0.6 $\mathrm{MPa}$ contributed equally to two variables each (Table 1). In this way, the stress of $-0.2 \mathrm{MPa}$ stands out as being the most suitable as a potential stress level for discrimination of genotypes tolerant and susceptible to drought imposed during the germination process.

Rossetto et al. (1997) reported that the percentage of germination of soybean seed lots is reduced when water is retained in the substrate at tensions of approximately $-0.2 \mathrm{MPa}$, which is the most influential potential with respect to genetic diversity. Soltani et al. (2006) observed in a study with wheat that there was an interaction between genotype $\mathrm{x}$ level of osmotic potential applied during germination, and showed that significant differences among genotypes were clearer in stress levels smaller than $-1.5 \mathrm{MPa}$, much larger than the potential evaluated in the present study; however, in different species.

The vigor of seed can be affected by many factors and can be expressed by germination, root, and shoot length, fresh and dry mass of seedlings, germination test in cold or high temperature condition, reserve dynamics and others, as shown in Table 1. The aforementioned characteristics are controlled by multiple genes, being of quantitative nature (Dickson, 1980), affected by environmental factors during seed maturation, harvest and storage, which makes genetic analysis of seed vigor too hard (Sun et al., 2007).

An alternative when trying to analyze so many variables and optimize the efficiency of selection in genetic studies is selecting features with greater influence, especially in situations requiring the evaluation of many genotypes. For this, we used an analysis of importance of characters in different stress levels (Figure 2).

As much as the level of stress increased, characteristics related to dynamic reserves also increased influencing the diversity. In all stress conditions (Figure 2B, C, and D), among

Genetics and Molecular Research 16 (2): gmr16029654 

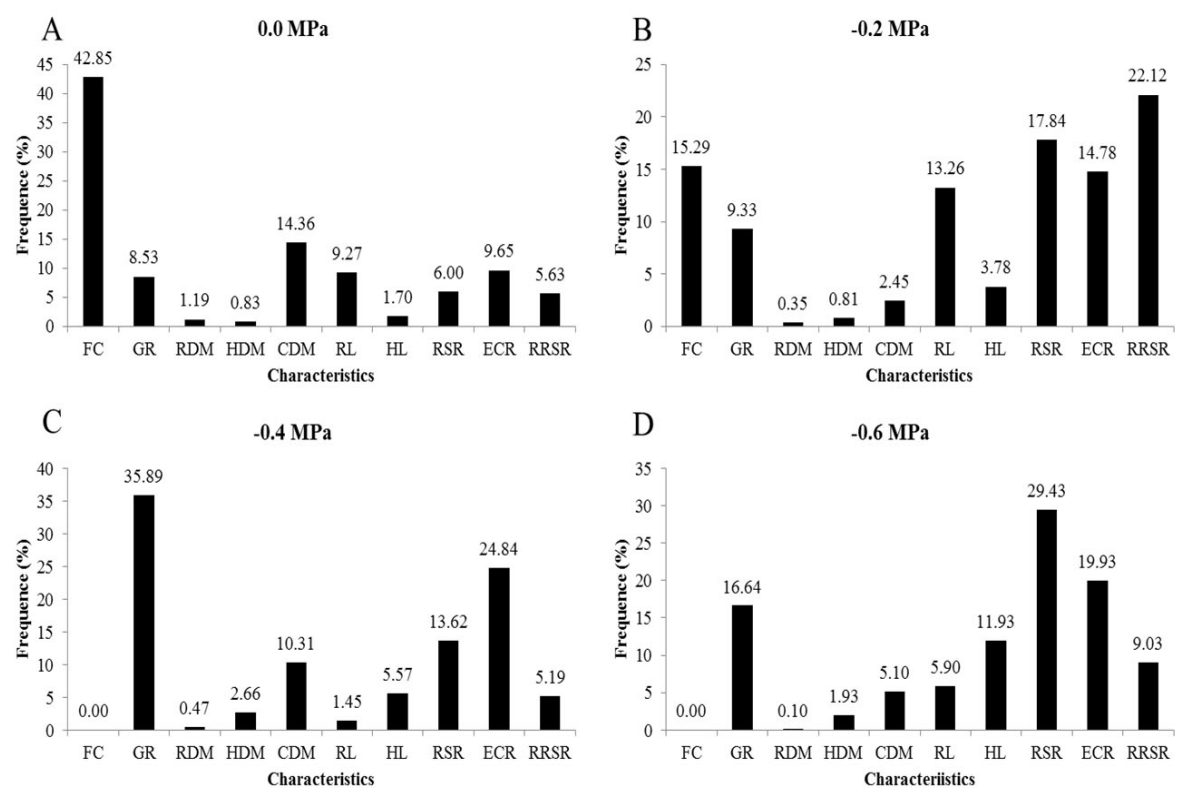

Figure 2. Relative importance of various characteristics to the genetic diversity of 13 soybean genotypes at four levels of stress (osmotic potentials) induced by PEG-6000 during germination. FC - first count; GR - germination; RDM, HDM, and CDM - dry mass of root, hypocotyl, and cotyledons; RL and HL - root and hypocotyl length; RSR - reduction of seed reserves; ECR - efficiency of conversion of reserves; RRSR -reduction rate of seed reserves.

the three characteristics that had the most influence on the genetic diversity, at least two in each stress level were related with dynamics of reserves and with RRS emphasis, which was always the second most important feature. This demonstrates the importance of using these variables to distinguish the most tolerant and the most sensitive genotype.

The first count and germination are highly important under all environmental conditions. However, as they increase, the stress levels at the first count lose influence on the germination and other remaining characteristics, which delay the germination of seeds. Moreover, not always the seed germination ensures the establishment of the plant, if it does not have sufficient reserves to appropriate initial seedling growth. For this reason, the properties related to the dynamics of reserves emerge as potential features for selection of genotypes tolerant to stress conditions.

The RSR, or remaining dry mass in cotyledons, is indicative of how much the initial reserve present in cotyledon was relocated during the stage of seed germination, i.e., the higher the RSR more energy is available to the process of germination. Features of use of seed reserves, like RSR, play important roles in seed vigor, implementing its germination and heterotrophic growth (Cheng et al., 2013).

Seed germination is followed by the mobilization of cotyledon reserves, providing essential energy to feed seedling growth until the seedling becomes photoautotrophic. Because of the significance of this process during and after germination, the mobilization of reserves during germination has been widely studied (Pritchard et al., 2002).

There are disagreements about the amount of energy available to seeds and its effective use (ECR), that is, processing as dry matter (Pereira et al., 2015). These variables 
are greatly influenced by seed size and initial mass (Soltani et al., 2006). Therefore, a simple linear correlation analysis was performed between these assessed characteristics in soybean genotypes subjected to a stress level of $-0.2 \mathrm{MPa}$ (Table 2), which is the level of stress that provided the greatest expression of genetic variability.

Table 2. Estimated phenotypic correlation coefficients for various characteristics based on the averages of the evaluated cultivars under water stress level of $-0.2 \mathrm{MPa}$.

\begin{tabular}{l|c|c|c|c|c|c|c|c|c|c|c}
\hline & FC & GR & RDM & HDM & CDM & RL & HL & RSR & ECR & RRSR & SDM \\
\hline FC & - & 0.20 & $0.61^{*}$ & -0.09 & 0.15 & 0.42 & -0.02 & -0.08 & -0.03 & -0.10 & 0.09 \\
\hline GR & - & - & 0.44 & -0.05 & 0.40 & 0.42 & 0.29 & -0.42 & 0.28 & -0.44 & 0.06 \\
\hline RDM & - & - & - & 0.48 & -0.14 & $0.87^{* *}$ & 0.38 & 0.27 & -0.25 & 0.24 & 0.19 \\
\hline HDM & - & - & - & - & -0.44 & 0.49 & $0.55^{*}$ & $0.64^{*}$ & -0.54 & $0.63^{*}$ & 0.31 \\
\hline CDM & - & - & - & - & - & -0.20 & -0.10 & $-0.74^{* * *}$ & $0.81^{*}$ & $-0.87^{* *}$ & 0.31 \\
\hline RL & - & - & - & - & - & - & 0.50 & 0.29 & -0.42 & 0.30 & 0.15 \\
\hline HL & - & - & - & - & - & - & - & 0.37 & -0.37 & 0.32 & 0.38 \\
\hline RSR & - & - & - & - & - & - & - & - & $-0.73^{* *}$ & $0.98^{* *}$ & 0.40 \\
\hline ECR & - & - & - & - & - & - & - & - & - & $-0.81^{* *}$ & 0.06 \\
\hline RRSR & - & - & - & - & - & - & - & - & - & - & 0.20 \\
\hline SDM & - & - & - & - & - & - & - & - & - & - & - \\
\hline
\end{tabular}

FC - first count; GR - germination; RDM, HDM, and CDM - dry mass of root, hypocotyl, and cotyledons; RL and HL - root and hypocotyl length; RSR - reduction of seed reserves; ECR - efficiency of conversion of reserves; RRSR - reduction rate of seed reserves; SDM - seed dry mass. *,***** Significant at 5, 1 and $0.01 \%$ probability by the $t$-test.

According to the results in the potential of $-0.2 \mathrm{MPa}$, no correlation were found between seed size and the characteristics related to the reservation dynamics, showing that the initial seed size does not influence at all the vigor of the seed.

In conclusion, we observed that germination test driving under water stress, induced by PEG-6000 and osmotic potential of $-0.2 \mathrm{MPa}$ is efficient for the exploitation of greater genetic variability between soybean genotypes; and that the percentage of germination and analysis of seed reserve dynamics are potential variables to be considered when selecting genotypes tolerant to drought during germination.

\section{ACKNOWLEDGMENTS}

The authors would like to thank Conselho Nacional de Pesquisa $(\mathrm{CNPq})$ and Coordenação de Aperfeiçoamento de Pessoal de Nível Superior (CAPES) for financial support and $\mathrm{PhD}$ granting scholarship.

\section{REFERENCES}

Brasil (2009). Ministério da Agricultura e Reforma Agrária. Regras para análise de sementes. SNAD/DNDV/CLAV, Brasília.

Cheng X, Cheng J, Huang X, Lai Y, et al. (2013). Dynamic quantitative trait loci analysis of seed reserve utilization during three germination stages in rice. PLoS One 8: e80002. http://dx.doi.org/10.1371/journal.pone.0080002

Cruz CD (2013). GENES - A software package for analysis in experimental statistics and quantitative genetics. Acta Scientiarum 35: 271-276.

Dickson MH (1980). Genetic aspects of seed quality. Hortic. Sci. 15: 771-774.

Henning FA, Mertz LM, Jacob Jr EA, Machado RD, et al. (2010). Composição química e mobilização de reservas em sementes de soja de alto e baixo vigor. Bragantia 69: 727-734. http://dx.doi.org/10.1590/S0006-87052010000300026

Kosturkova G, Todorova R, Sakthivelu G, Akitha Devi MK, et al. (2008). Response of bulgarian and indian soybean

Genetics and Molecular Research 16 (2): gmr16029654 
genotypes to drought and water deficiency in field and laboratory conditions. Gen. Appl. Plant Physiol. 34: 239-250.

Marrou H, Vadez V and Sinclair TR (2015). Plant survival of drought during establishment: an interspecific comparison of five grain legumes. Crop Sci. 55: 1264-1273. http://dx.doi.org/10.2135/cropsci2014.11.0760

Mederski HJ and Jeffers DL (1973). Yield response of soybean varieties grown at two soil moisture stress levels. Agron. J. 65: 410-412. http://dx.doi.org/10.2134/agronj1973.00021962006500030017x

Oya T, Nepomuceno AL, Neumaier N, Farias JRB, et al. (2004). Drought tolerance characteristics of brazilian soybean cultivars -evaluation and characterization of drought tolerance of various brazilian soybean cultivars in the field. Plant Prod. Sci. 7: 129-137. http://dx.doi.org/10.1626/pps.7.129

Pereira WA, Pereira SMA, Dias DCFS (2015). Dynamics of reserves of soybean seeds during the development of seedlings of different commercial cultivars. J. Seed Sci. 37: 063-069.

Pritchard SL, Charlton WL, Baker A and Graham IA (2002). Germination and storage reserve mobilization are regulated independently in Arabidopsis. Plant J. 31: 639-647. http://dx.doi.org/10.1046/j.1365-313X.2002.01376.x

Rossetto CAV, Novembre ADL, Marcos Filho J, Silva WD, et al. (1997). Comportamento das sementes de soja durante a fase inicial do processo de germinação. Sci. Agric. 54: 106-115. http://dx.doi.org/10.1590/S0103-90161997000100015

Santos ER, Barros H, Capone A, Melo A, et al. (2012). Divergência genética entre genótipos de soja com base na qualidade de sementes. Agraria 7: 247-254. http://dx.doi.org/10.5039/agraria.v7i2a1560

Singh D (1981). The relative importance of characters affecting genetic divergence. Indian J. Genet. Plant Breed. 41: 237-245.

Soltani A, Zeinali E and Galeshi S (2001). Genetic variation for and interrelationships among seed vigor traits in wheat from the Caspian Sea coast of Iran. Seed Sci. Technol. 29: 653-662.

Soltani A, Galeshi S, Zeinali E and Latifi N (2002). Germination, seed reserve utilization and seedling growth of chickpea as affected by salinity and seed size. Seed Sci. Technol. 30: 51-60.

Soltani A, Gholipoor M and Zeinali E (2006). Seed reserve utilization and seedling growth of wheat as affected by drought and salinity. Environ. Exp. Bot. 55: 195-200. http://dx.doi.org/10.1016/j.envexpbot.2004.10.012

Sun CX, Shen XY and Gu TS (2001). Relationship between seed germination and its drought resistance of shoot-seedling in different genotype maize. Seed 5: 32-35.

Sun Q, Wang J and Sun B (2007). Advances on seed vigor physiological and genetic mechanisms. Agric. Sci. China 6: 1060-1066. http://dx.doi.org/10.1016/S1671-2927(07)60147-3

Teixeira LR, De Lucca A, Braccini DS, Scapim CA, et al. (2008a). Avaliação de cultivares de soja quanto à tolerância ao estresse hídrico em substrato contendo polietileno glicol contendo polietileno glicol contendo polietileno glicol. Acta Sci. Agron. 30: 217-223.

Teixeira LR, Braccine ADL, Sperandio D, Scapim CA, et al. (2008b). Avaliação de cultivares de soja quanto à tolerância ao estresse hídrico. Ceres 55: 194-202.

Vanzolini S, Araki CAS, Silva ACTM and Nakagawa J (2007). Teste de comprimento de plântulas na avaliação da qualidade fisiológica de sementes de soja. Rev. Bras. Sem 29: 90-96. http://dx.doi.org/10.1590/S0101-31222007000200012

Villela FA, Doni Filho L and Sequeira EL (1991). Tabela de potencial osmótico em função da concentração de polietilenoglicol 6000 e da temperatura. Pesqui. Agropecu. Bras. 26: 1957-1968.

Yu SB, Chen WZ and Xu CG (1999). Genotypic variation of seed vigor in rice. Seed 2: 24-26.

Genetics and Molecular Research 16 (2): gmr16029654 